АМЕРИКАНСЬКИЙ ДОСВІД КОРПОРАТИВНОГО НАВЧАННЯ МЕДІАКОМПЕТЕНТНОСТЕЙ

\title{
AMERICAN EXPERIENCE IN ON-THE-JOB DEVELOPMENT OF MEDIA COMPETENCE
}

УдК 37.01

DOI https://doi.org/10.32843/2663-

6085/2020/24-1.24

\section{Головченко Г.О.,}

канд. пед. наук, директор

Коледжу преси та телебачення,

секретар

Національної спілки журналістів

України,

генеральний продюсер

Телеканалу TAK TV у статті наголошується на важливості виховання медіаграмотної особистості для свідомого використання інфрормаційного контенту. Актуальність проблеми виховання медіакомпетентності в економічно активного населення зумовлена тим, що сучасний працівник повинен вільно володіти цисрровими та медіанавичками, які сприяють підвищенню конкурентноздатності кожного працівника та зростанню продуктивності економіки країни. В дослідженні автор виділяє види професійної діяльності осрісних працівників, що потребують цисррові та медіавміння.

Здійснений аналіз найкращих практик провадження медіаосвітньої діяльності на робочому місці в США дав змогу зробити висновок щодо поліфункціональності навчання на робочому місці, якому притаманні інтегративна, мотиваційна, розвивальна, випереджальна функції. Наголошено на необхідності організації роботодавцями навчання своїх працівників з метою розвитку цифроової та медіакомпетентності та отримання організаціями засобів власного розвитку, розвитку свого персоналу та його утримання. Враховуючи те, що навчені цисрровим та медіанавичкам працівники принесуть економічну користь своїй компанії, соціальну вигоду громаді та суспільству загалом, у США було розроблено довгострокову стратегію щодо покращення цифррової та медіаграмотності різних соціальних та економічних верств населення для підвищення продуктивності та конкурентноздатності майбутніх поколінь. Виявлена основна мета медіаосвітніх програм, що полягає не лише у розвитку базових навичок користування цифрровими і медіаресурсами, але й створення власної медіапродукції, а для працівників вищого управлінського рівня - у подальшому розвитку їхньої медіакомпетентності як складники розвитку лідерських якостей. Вивчення автентичних джерел дало можливість виявити особливості сучасних форм організації корпоративної медіаосвіти в США: інсорсингової та аутсорсингової. Закцентовано на урядовій підтримці тих компаній, які забезпечують цифррове та медіанавчання працівників на їхньому робочому місці шляхом різних податкових пільг. Автор привертає увагу до популярності таких програм в американському суспіль- стві, їх економічної користі для організацій та позитивної соціальної ролі.

Ключові слова: медіакомпетентність, працівник, навчання на робочому місці, корпоративні клієнти, громадські організації, США.

The article stresses the importance of raising a person's media literacy for conscious use of information content. Urgency of media literacy of economically active population is explained by the fact that modern employer should have digital and media skills, which enhance increasing every employer's competitiveness and productivity in the country. In the research the author distinguishes types of office workers who need digital and media skills.

The carried out analysis of the best practices of implementation of media on-the-job training in the USA allowed the author to make a conclusion about poly functionality of on-the-job-training, characterized by integrative, motivating, developing, forward-looking functions. The necessity to establish employers' training aimed at raising digital and media competency has been drawn attention to, as well as acquiring methods of corporate development, professional development of employers and their sustaining. Taking into consideration the fact that employers with digital and media skills can bring economic benefit to their company, social benefit to the community and society, in the USA long-term strategy of improvement of media literacy of different social and economic types of population for competitiveness was worked out. The main purpose of media educational programs which underpins not only the development of user's basic skills of digital and media resources but creation of own media production, and for employers of higher managerial level - in further development of their media competences has been identified. The analysis of authentic resources gives opportunity to find out peculiarities of modern forms of corporate media education in the USA: insourcing and outsourcing. Governmental support of the companies that provide digital and media on-thejob education in the form of tax credits has been highlighted. The author draws attention to the popularity of such programs in American society, their economic benefit for organizations and positive social influence.

Key words: media competence, employer, onthe-job training, corporate clients, nongovernmental organizations, the USA.
Постановка проблеми. В останні два десятиріччя минулого століття підвищена увага дослідників спостерігається у вивченні питання корпоративної підготовки як необхідної умови конкурентоспроможності підприємств. Знання набувають функцію головного ресурсу організації. У наукових працях наголошується на необхідності постійно підвищувати профресіоналізм працівників, адже це основна вимога сучасного світу праці.
Компанії зосереджують свою увагу на критичному аналізі результатів діяльності та намагаються знайти шляхи поліпшення цих результатів. Зважаючи на те, що «жодна людина або компанія не може знати все достатньою мірою» (К. Воткінс) [13], корпоративна підготовка стає вагомим внеском в ефективне виробництво, тому їй слід надавати більше уваги, вона повинна мати високий статус та достатнє фрінансування. 
Дослідження науковців свідчать про те, що корпоративна освіта у США вирізняється складністю та багатоаспектністю, що зумовлено міждисциплінарністю іiї теоретичних засад, які ґрунтуються на поєднанні економічних, управлінських, психологічних та педагогічних теорій i концепцій. У цьому контексті слушною $€$ думка академіка Н. Ничкало, що проблеми розвитку системи професійної освіти й навчання охоплюють великий комплекс питань, які межують із психологією, педагогікою, психофізіологією, економікою, ергономікою, соціологією, статистикою та іншими галузями наукового знання [2, с. 36-37].

Обираючи для аналізу медіаосвітні практики на робочому місці, ми керувалися теорією «медіа освіти», запропоновану С. Левінгстон (S. Livingston). Вчена розглядає медіаосвіту як інформаційну компетентність, що має різні виміри. Перший вимір - соціально-політичний - пов'язаний з демократією та активною участю кожного у житті суспільства. Медіаосвічені люди, з цього погляду, $€$ поінформованими, відповідальними громадянами. В контексті загальноприйнятого визначення терміну «медіаосвіта» - це здатність отримувати, розуміти та оцінювати медіаповідомлення чи будьяку інформацію, що дозволяє стати поінформованими, здатними незалежно та критично думати. Їхнє уміння створювати медіаповідомлення дозволяє їм бути почутими у суспільстві [7]. Як відзначає B. Поттер (W. Potter), такий погляд на медіаосвіту акцентує потребу кожного індивіда на його вмінні абстрагуватися від впливу масмедіа [9].

Таким чином, саме критичне мислення набуває вагомості у розумінні медіаосвіти сучасної людини як члена громади і суспільства. Інший вимір, за С. Лівінгстон, стосується економіки знань, конкурентоспроможності та вибору. У цьому разі індивіда розглядають у його/їі відношенні до економіки, а саме ринкової економіки з двох позицій: як споживача та як працівника. Як споживач медіаосвічена особа здатна збільшити свої знання, отримуючи достатньо інформації з Інтернетджерел, та зробити виважений вибір. Іншими словами, медіаспоживач повинен бути здатним розпізнавати і передбачати стратегії рекламодавців стосовно тієї продукції чи послуг, які бажає придбати. Ця риса медіаосвіти рівноважлива для усіх членів суспільства. Нарешті, медіаосвіченість особи, на думку С. Лівінгстон, також полягає в її умінні отримувати, вибирати й оцінювати інформацію, що стосується іiі професійної діяльності, та створювати медіаповідомлення в межах своїх робочих обов'язків 3 метою досягнути більшого на робочому місці. Можливо, підняти свій рівень можливої зайнятості на ринку праці та підвищити свою конкурентоздатність. Але, як і у першому разі, медіаосвіта розглядається дослідницею в соціальному контексті, тобто її спрямованість можна вважати не чисто економічною, а соціально-економічною.
Аналіз останніх досліджень і публікацій. Аналіз останніх наукових досліджень свідчить про значене зростання наукових доробків, присвячених проблемі корпоративної підготовки виробничого персоналу. У сучасних умовах набуло актуальності вивчення впливу глобалізаційних процесів на розвиток освіти (В. Андрущенко, В. Кремень, Н. Лавриченко, О. Матвієнко, А. Сбруєва, О. Сухомлинська), проблем неперервної освіти (Б. Вульфрсон, О. Владиславлєв, О. Даринський, І. Зязюн, 3. Малькова, Н. Ничкало), розвитку післядипломної освіти (В. Крижко, А. Кузьмінський, В. Олійник та інші), особливостей інтеграції освіти у геополітичних регіонах (Є. Бражнік, В. Луговий, О. Олейникова, П. Сікорський та інші). Зростає увага дослідників до вивчення проблем формування людського капіталу та його менеджменту в системі профресійної підготовки як чинника конкурентоспроможності підприємства (О. Грішнова, В. Кірьян, І. Кочума, 3. Магамедінова, О. Попов, T. Синиця). Питання корпоративного навчання в США порушувались І. Литовченко. Водночас багато українських науковців присвятили свої праці визначенню медіаосвіти та медіаграмотності, концептуальних підходів до їх розуміння, рис схожості та відмінностей. Праці О. Волошенюк, Л. Кульчинської, Ю. Мірошниченко, Л. Найдьонової та інші, присвячені вивченню медіаосвіти як соціально-психологічної моделі за характером взаємодії суб'єктів та як психологічного новоутворення. В багатьох дослідженнях вивчається розвиток медіакомпетентності (В. Іванов, Т. Іванова). Аналіз основних медіаосвітніх підходів і теорій був викладений у наукових розвідках зарубіжних дослідників (Л. Мастерман, Ж. Пьетт, Л. Жир, Ж. Гонне). Проте слід зазначити, що вітчизняними науковцями не здійснювався аналіз особливостей корпоративного розвитку медіакомпетентностей економічно активного населення в США.

Мета статті - аналіз питання виховання медіакомпетентності у системі несормальної освіти в США

Відповідно до зазначеної мети у статті поставлені такі завдання:

1. Проаналізувати проблему набуття медіакомпетентності різними категоріями населення, у тому числі економічно активним населенням, на робочому місці.

2. Розкрити зміст навчальних ресурсів, що пропонуються громадськими медіаосвітніми організаціями.

3. Виявити цілі медіаосвіти для різних категорій економічно активного населення, що пропонується неформальною освітою в США.

Теоретичні основи дослідження становлять: фрілософські концепції функціонування і розвитку освітніх систем у контексті глобалізації (Б. Гершунський, І. Зязюн, В. Кремень, В. Кудін, А. Ліфьоров, В. Лутай та інші); теорії фрормування людського 
капіталу (Г. Беккер, О. Грішнова, Г. Дмитренко, Я. Мінсер, В. Онікієнко, А. Чухно, Т. Шульц); теорії неперервної професійної освіти та освіти дорослих (С. Батишев, Г. Беднарчик, І. Вільш, С. Гончаренко, В. Луговий, Л. Лук'янова, Н. Ничкало, В. Олійник та інші); концептуальні положення порівняльної педагогіки (Н. Бідюк, В. Вульфссон, І. Литовченко, О. Матвієнко, О. Огієнко, Л. Пуховська, О. Сухомлинські та інші).

Методи дослідження. Для досягнення мети та виконання поставлених завдань використовувалися методи дослідження: загальнонаукові (аналіз, синтез, порівняння, узагальнення), що $€$ основними засобами вивчення наукових джерел; конкретно-наукові - компаративний (аналіз методологічної, соціально-педагогічної, фрілософської, економічної літератури; аналіз і узагальнення зарубіжних сучасних підходів до організації профресійної підготовки виробничого персоналу); семантико-термінологічний (виявлення динаміки змістового наповнення поняттєво-термінологічного апарату дослідження); пошуковий (формування узагальнених висновків, оцінок, виявлення раціонального і практично-ціннісного в наукових працях з порівняльної педагогіки).

Виклад основного матеріалу. Проведений аналіз наукових джерел дозволяє нам говорити про те, що корпоративна освіта в США має гнучку, адаптивну, диверсифіковану структуру, яка складається з розгалуженої мережі навчальних закладів та структурних підрозділів організації, що використовують освітню фрункцію, профресійних організацій, громадських організацій, компанійвиробників, інших освітніх провайдерів та корпоративних програм різноманітного змістового спрямування [1, с. 178].

Медіаосвіта кожного, у тому числі й будь-якого працівника, має розглядатися передусім з позиції іiї важливості для суспільства, для особистих та професійних цілей. Іншими словами, сучасного працівника необхідно розглядати як працюючого громадянина, який вільно володіє цифровими та медіа навичками, адже у сьогоднішньому світі вони $€$ найбільш важливими та затребуваними. Вони сприяють підвищенню конкурентоздатності кожного працівника та зростанню продуктивності економіки країни. Навіть більше, очікується, що професії майбутнього будуть повністю залежати від здатності та уміння людини безперервно навчатися та вирішувати проблеми, використовуючи цілий спектр своїх циоррових умінь.

Навіть такі рутинні завдання на робочому місці, як підрахунки, спілкування з клієнтами чи реклама у соціальних медіа, потребують цифрових навичок, не кажучи вже про здійснення онлайн-платежів, електронні рахунки, онлайн-ринок чи електронну комерційну діяльність підприємства. Широке використання технологічних новинок, швидкий технологічний поступ в робототехнологіях та сфрері штучного інтелекту кардинально та швидко змінюють робоче місце сучасного працюючого і висувають до нього/неї високі вимоги. Так, обсяги інформації, що невпинно збільшуються, вимагають від сучасних працівників таких умінь, які допоможуть їм уникнути інорормаційного перенавантаження. Теле- та відео технології вже стали звичними, тому спілкування та координація роботи кількох працівників за їхньою допомогою також не є дивиною. Мобільні технології вимагають від працівників повсякчасного виконання професійної діяльності у мобільному контексті.

Фактично цифрові технології настільки змінили робоче місце будь-якого працівника, що науковці навіть ведуть мову про френомен NWOW - new ways of working, що в перекладі з англійської означає «нові способи праці». Їх основною рисою стає не лише виконання безпосередніх службових обов'язків, але й соціальна інклюзія та активне громадянство [3, с. 122].

Отже, мають місце докорінні зміни робочого середовища. Прикметно, що наслідком цих змін $\epsilon$ не лише технічні та технологічні характеристики, але й, як зазначалося вище, певні соціальні вимоги. Ці зміни своєю чергою потребують нових знань, умінь та навичок від працівника. Нині затребувані ринком праці компетентності виходять за рамки якісного виконання лише своїх функційних обов'язків. Те, що вимагається від сучасного працівника, - питання інклюзії та добробуту як власного, так і організації свого працевлаштування, громади і суспільства загалом [3, с. 123]. Соціальне життя фрормує запит на необхідні компетентності, навички і вміння працівника будь-якої сорери діяльності. I саме соціальне життя надало медіанавичкам працівника такої вагомості.

У контексті робочого середовища логічніше було б вести мову не просто про медіакомпетентність працюючого, а про його/їі цифрові та медіанавички. Нам імпонує бачення групи зарубіжних науковців, які пропонують розглядати цифрову та медіакомпетентності працюючих, зокрема офрісних працівників, 3 погляду рівня застосування ними своїх цифррових і медіанавичок у професійній діяльності. Так, спочатку дослідники виділили ті види професійної діяльності офрісних працівників, де потрібно використовувати свої цифрові та медіавміння, а саме: створення документу, передача низки документів, управління вхідною та вихідною документацією, доручення іншим знайти потрібну інфрормацію, прийняття рішення про розподіл обов'язків, ролей, фрункцій та загальне керування процесом, планування, планування діяльності відділу, синхронна співпраця з іншими відділами, організація та облаштування робочого місця для ефрективної співпраці. На основі вивчення виокремлених видів діяльності, а також ураховуючи 
ступінь застосування працівниками своїх цифррових та медіаумінь за допомогою анкетування та інтерв'ю, дослідники будують дві моделі цифрової та медіаосвіченості сучасного офрісного клерка.

У першій моделі медіаосвіта працівника сприймається насамперед як набір базових навичок (навіть не компетентностей), що дозволяють клерку виконувати свої професійні обов'язки, передбачені вимогами організації чи компанії. Коротше кажучи, від працівника очікується, що він/ вона вміють чи навчаться використовувати ті технічні засоби, що їх надає працедавець, і зможуть якісно виконати поставлені завдання. У другій моделі працівники не просто вміють і використовують нові технології у своїй діяльності, але й проявляють певну винахідливість упродовж своєї трудової діяльності. Таким чином, враховуючи рівень використання своїх цифрових та медіанавичок, першу модель дослідники назвали моделлю відповідності», іншу - «моделлю винахідливості» [3].

Однак нас цікавить не просто рівень цифрових і медіанавичок працюючих, а сам медіаосвітній процес, завдяки якому працівники набувають необхідних навичок і вмінь. Для отримання об'єктивної картини потрібно звернутися до аналізу найкращих практик провадження медіаосвітньої діяльності на робочому місці. 3 цією метою ми умовно поділимо усі професії та робочі місця на три категорії:

- ті, що безпосередньо пов'язані з медіа;

- ті, завдяки яким провадиться медіаосвітня діяльність;

- ті, які не мають стосунку до медіа.

Перша категорія професій потребує профресійної медіаосвіти, здобутої у фрормальному освітньому середовищі. До них належать насамперед журналістика та пов'язані $з$ нею професії. Розширити свої знання з медіаосвіти, поглибити наявні медіанавички, розвивати цифрову компетентність представники цієї групи можуть у неформальній та інформальній освіті, як і будь-який представник суспільства, в якому вони проживають і працюють.

Відтак на аналізі та прикладах провадження медіаосвітньої діяльності на робочому місці, зокрема в журналістиці чи інших сорерах діяльності, пов'язаних з медіа, ми не будемо зупинятися. Це потребує окремого додаткового дослідження. Друга категорія охоплює педагогічні профресії - вихователя дитячого садка, учителя молодшої, середньої та старшої школи, тренера, фрасилітатора, модератора, викладача, бібліотекаря, працівника музеїв та інших. Набуття необхідних цифрових і медіанавичок цією категорією працівників можливе як у фрормальній, так і в неформальній / інформальній освіті.

Зупинимося на третій категорії професій i 3'ясуємо, чи потрібні медіанавички працівникам, які не мають жодного стосунку до медіа чи медіаосвітньої діяльності. Важливість навчання саме на робочому місці доведено статистикою. Прикметно, що розвиток суто медіанавичок працівників відбувається в межах базових освітніх програм, а цифрових навичок у межах навчання 3 інформаційних технологій.

У сьогоденних умовах 74\% американців використовують комп'ютер на своєму робочому місці [8]. Відтак можна з упевненістю стверджувати, що IT технології проникли майже у всі професії від високо- до низько-кваліфрікованих. Необхідність володіння працівниками навичками використання цифрових засобів, у тому числі й медіа, змушують працедавців організовувати навчання своїх працівників. Американське товариство з навчання та розвитку (ASTD - American Society for Training and Development) проаналізувало діяльність 2500 фрірм на предмет навчання працівників. Було з'ясовано, що ті організації, що провадили цілісне навчання своїх працівників, отримували дохід на 218\% вище 3 розрахунку на кожного працівника, ніж ті компанії, що навчали винятково виконанню профресійних обов'язків [12].

Зазначимо, що особи, які не мають IT навичок, вважаються «цифрово неграмотними» (digitally illiterate). Навіть у США він становить 16\%. У порівнянні 3 міжнародним рівнем (23\%) він нижчий. Звертає на себе увагу той фракт, що рівень цифрової неграмотності залежить від рівня освіти особи. Біля 2/5 (41\%) дорослих американців, які не закінчили школу, 17\% американців, які закінчили школу, але не коледж, і 5\% дорослих, які не мають вищої освіти, є циоррово неосвіченими [10].

Невміння працівників користуватися сучасними IT означає їхню неспроможність якісно виконувати свої професійні обов'язки, а також бути активними членами суспільства, оскільки відсутність медіаграмотності стає для них непереборною перепоною. Згідно з даними Adobe організації, що прагнуть цифрової досконалості, навчають і розвивають цифрові навички своїх працівників. Вони визнають, що навчання та можливість особистісного та професійного розвитку стають головним пріоритетом для сучасних працівників. Без такої пропозиції від організації працівники почуваються «не стимульованими та розчарованими» [12]. Якщо ж організації забезпечують таким навчанням, працівники розвивають свою цифрову та медіакомпетентності, а самі організації отримують могутній засіб власного розвитку, розвитку свого персоналу та засобу його утримання. Враховуючи теорію С. Лівінгстон, навчені цифровим та медіанавичкам працівники принесуть економічну користь своїй компанії, собі як в особистому, так і у в профресійному вимірах, і врешті, соціальну вигоду громаді та суспільству загалом.

Метою медіаосвітніх програм має стати не лише розвиток базових навичок користування 
цифровими і медіаресурсами, але й створення власної медіапродукції. Попри те, що американські компанії висвітлюють в Інтернеті свою діяльність, місію, візію, стратегічні плани розвитку, можливості навчання для своїх працівників та багато іншого, інфрормація про зміст навчання на робочому місці вважається ноу-хау [6]. Тому на сайтах компаній ця інформація, якщо і наявна, проте має рекламний характер, що унеможливлює ії аналіз та систематизацію за певними критеріями. 3 огляду на зазначене ми проаналізували наявні в Інтернеті освітні пропозиції для бізнес-компаній, фрірм, організацій. Логічно було припустити, що для розвитку цифрової та медіакомпетентностей працівники компанії звертаються до аутсорсингу (від англ. outsourcing - угода, за якою певні завдання компанії передаються для виконання експертам у цьому виді робіт).

Таким чином, ми з'ясували, що американські компанії віддають перевагу експертам 3 цифрової та медіаосвітньої діяльності - відомим громадським медіаосвітнім організаціям, які підбирають навчальні програми відповідно до потреб компанії-замовника. Навіть більше, представники медіаосвітніх організацій, медіаосвітні тренери, фасилітатори, педагоги провадять навчання на території замовника. Кожна громадська медіаосвітня організація пропонує низку навчальних ресурсів саме для корпоративних клієнтів. Такі програми користуються попитом, зокрема з розвитку цифрових навичок та використання соціальних медіа. Не дивно, адже за їхньою допомогою працівники компанії-замовника створюють імідж компанії, просувають на ринку свій бренд, залучають більше клієнтів, просто спілкуючись у соціальних мережах чи у різних групах онлайн [5] Наведемо приклад, які рекомендації 3 використання соціальної мережі LinkedIn.

Рекомендації пропонуються для просування своєї компанії та її продукції. Серед 5 ключових рекомендацій найбільш результативними можна вважати введення посади менеджера з соціального спілкування та навчання персоналу соціальним медіанавичкам [6]. Його переваги для компанії очевидні. Так, соціальний медіаменеджер надсилає електронного листа працівникам, що потрібно поширити певний контент, до якого прикріплюється посилання на фрірму та її діяльність чи продукцію Кожен зі співробітників поширює інфрормацію у своїх групах в соціальній мережі. Якщо вони мають необхідні соціальні медіанавички, це просто і легко. Тому варто навчати працівників умінню поширювати інорормацію у групах.

Для цього насамперед потрібно навчитись, як завоювати довіру у цільовій групі. Це можливо лише через виважені, добре обдумані коментарі до дискусій, які вже провадяться у групі чи на форумі. Також необхідно ділитися інформацією від інших учасників групи, а не лише поширювати контент про свою фрірму, щоб уникнути слави рекламодавця. Крім того, доцільно розпочати нове обговорення в групі, ставлячи короткі, але серйозні запитання. Якщо нова дискусія розпочалася, потрібно реагувати на кожен коментар. Навчання соціальним медіа проводить на робочому місці менеджер з соціального спілкування.

Розуміння різних медіа та їх впливу нині стає життєво необхідною навичкою для лідера. Постійний інформаційний потік через новини, телевізійні програми, електронні книги, соціальні мережі фрормує навички сприйняття, розуміння та оцінювання інфрормації, навколишнього світу та того, чим він живе. Медіаосвічені лідери здатні виконувати свої обов'язки найкраще. CNBC (американський кабельний і супутниковий канал новин для бізнесу) оприлюднив результати дослідження, що CEO (chief executive officers), тобто генеральні директори чи топ-менеджери компанії, які активні в соціальних мережах, кращі керівники, ефективніші комунікатори, ніж ті, хто не використовує свої цифрові та медіанавички. Вони мають більший доступ до необхідних знань, можуть краще донести до рядових працівників і до суспільства стратегічні цілі компанії, поширювати інформацію на внутрішньому та зовнішньому ринках, завжди мають свіжі креативні ідеї, вміють адекватно оцінити отриману інформацію, використати соціальні мережі для створення іміджу компанії, прийняти вірне рішення і нести за нього відповідальність тощо. Зважаючи на це, громадські медіаосвітні організації також пропонують корпоративним клієнтам, тобто компаніям замовникам, програми 3 розвитку лідерських якостей, невід'ємною частиною яких $є$ розвиток цифрової та медіакомпетентностей керівників різних рівнів.

Іншим варіантом розвитку цифрової та медіакомпетентності працівників $€$ використання освітніх пропозицій відомих Інтернет-компаній чи офрісів соціальних мереж. Щодо цього цікавий досвід медіаосвітньої діяльності має відома соціальна мережа Facebook. 3 метою покращення свого суспільного іміджу компанія започаткувала програму "Community Boost" (у перекладі 3 англійської зростання спільноти).

Упродовж 2018 р. Facebook інвестувала десятки мільйонів доларів у навчання безробітних, підприємців початківців, власників сімейного бізнесу у 30-ти містах США. Серед основних завдань програми варто назвати такі:

- подальший розвиток цифрових і соціальних медіанавичок для пошуку робочого місця, оскільки $62 \%$ представників малого та середнього бізнесу у США, приймаючи рішення про прийом кандидата на роботу, керуються не тим, чи він/вона закінчили школу, а чи достатньо розвинені цифрові та медіанавички вони мають; 
- навчальна програма для підприємців, як використовувати технології для перетворення ідеї на бізнес та як, використовуючи Facebook, безкоштовно створити і забезпечити свою присутність онлайн;

- для власників бізнесу навчальна програма з розвитку цифрових та медіанавичок для розширення свого бізнесу, знаходження нових споживачів у своїй країні та у світі;

- для тих, хто вперше виходить в онлайн, Facebook пропонує програму навчання цифровій грамотності та онлайн безпеці;

- тих, хто прагне підтримати свою громаду, Facebook навчає, як використовувати цифрові технології та соціальні мережі для єднання членів суспільства за допомогою таких засобів, як Events (від англ. - події) чи Groups (від англ. - групи) [4,c. 64].

Технічні та інорормаційні гіганти, зокрема Google, Apple, Amazon та інші, також інвестують у навчання працівників, яке безпосередньо пов'язане з розвитком цифрових та соціальних медіанавичок, що покращує соціальну й економічну мобільність.

Висновки. Викладене вище дає підстави для висновку про те, що розвиток циорової та медіаграмотності працівників у США здійснюється переважно на робочому місці 3 використанням навчальних ресурсів, що пропонуються громадськими медіаосвітніми організаціями. До особливостей організації медіапідготовки працівників нами віднесено: гнучкість, мобільність, професійну спрямованість навчальних програм; індивідуалізацію та диореренціацію навчання; врахування професійного досвіду слухачів. Крім того, таке навчання, на відміну від медіаосвіти дітей молодих людей, насамперед націлено на розвиток цифрових навичок працівників. Лише навчання працівників вищого рівня - генеральних директорів та топ-менеджерів організацій - спрямовано на подальший розвиток їхньої медіакомпетентності як складника розвитку лідерських якостей. Загалом розвиток цифрової та медіакомпетентностей працівників приносить не лише економічну користь організації, яка його провадить, але й відіграє значну соціальну роль.

Подальші дослідження вбачаємо в аналізі підготовки ангдрагогічного персоналу для розвитку медіакомпетентностей економічно активного населення США.

\section{БІБЛІОГРАФІЧНИЙ СПИСОК:}

1. Литовченко І. Особливості організації навчального центру як структурного підрозділу для навчання працівників у американських компаніях. Педагогіка формування творчої особистості у вищій і загальноосвітній школах. № 52(105), 2017, с. 178-183.

2. Ничкало Н. 2008. Педагогіка і психологія праці в контексті розвитку людського капіталу. Педагогічна освіта і освіта дорослих: європейський вимір. І.А. Зязюна, Н.Г. Ничкало, Ред. Київ; Хмельницький, 2008, c. $30-40$.

3. Collard A-S. Digital media literacy in the workplace: a model combining compliance and inventivity I Collard, A-S., De Smedt, T., Dufrasne, M., Fastrez, P., Ligurgo, V., Patriarche, G. \& Philippette, T. Italian Journal of Sociology of Education. 2017. № 9(1). P. 122-154.

4. Costine T. Risk analysis in introduction of new technologies by start-ups in the Brazilian market / T. Costine, P. Oliva, M. Kotabe. Management Decision. 2018. № 1(56). P. 64-86.

5. Hobbs R. Digital and Media Literacy: A Plan of Action. Washington, D.C, The Aspen Institute, 2010. 67 p.

6. Ligurgo V. A method combining deductive and inductive principles to define work-related digital media literacy competences. I V. Ligurgo, T. Philippette, P. Fastrez, A-S. Collard \& J. Jacques. Communications in Computer and Information Science. 2018. № 8(10). P. 245-254.

7. Livingstone S. Taking risky opportunities in youthful content creation: teenagers' use of social networking sites for intimacy, privacy and self-expression. New Media \& Society. 2008. No. 3(10). P. 12-16.

8. Mamedova S. Description of U.S. Adults who are not digitally literate. / S. Mamedova, E. Pawlowski, L. Hudson. Washington, District of Columbia: National Center for Education Statistics, 2018. 33 p.

9. Potter W. J. Theory of Media Literacy: A Cognitive Approach. / W. Potter. SAGE Publications, 2004. 307 p.

10. Romero M. Digital literacy for parents of the 21st century children. Elearning Papers. 2014. № 38. P. 32-40.

11. Scull T. The impact of media-related cognition on children's substance use outcomes in the context of parental and peer substance use / T. Scull, J. Kupersmidt J. Erausquin. Journal of youth and adolescence. 2014. №5(43). P. 717-728.

12. Smith J. Media Literacy: A 21st Century Approach to Wellness. 2018. URL: heyjuliesmith.com/2018/02/17/ media-literacy-21st-century-approach-wellness/.

13. Watkins P. Knowledge and control in the flexible workplace. The changing workplace: Part B. Adult and workplace education, faculty of education, Deakin University, Geelong, Victoria, Australis. 1991. 187 p. 